\title{
Gatekeeping and the Conceptualization of World Literature in the Publishing Industry. The Case of Siegfried Unseld and Octavio Paz
}

The history of the reception of Latin American literatures in Germany cannot be understood without reference to Suhrkamp Verlag's publishing program in international literature. Siegfried Unseld, the head of the publishing house, who died in 2002, shaped the company's history for more than forty years and became the most important 'gatekeeper' (Marling) for Latin American authors in the Germanspeaking world over the course of that time. In establishing the selection criteria for his publishing program in international literature, Unseld followed the motto of the founder of the former Insel Verlag, Anton Kippenberg, understanding world literature as a biblioteca mundi, based on universal categories. A closer examination of the gatekeeping relationship between Siegfried Unseld and the Mexican writer Octavio Paz will allow us to see the degree to which this selection criterion of the universal, an idea that is hard to grasp within reception theory, was combined with the idea of the exotic in the context of the publishing house's Latin American program, which was developed starting in the late 1960s.

\section{The Material Foundation}

In December 2009, almost exactly thirty years after the first meeting between Paz and Unseld in May 1979, the entire estate of the Suhrkamp Verlag was transferred to the German Literary Archive (Deutsches Literaturarchiv, DLA) in Marbach, thereby increasing the total holdings of the Marbach archive by a quarter (Bürger 20). This Suhrkamp estate, in the words of George Steiner, constituted something akin to an international Suhrkamp culture, functioning as a seal of approval for world literature. The relocation of the company to Berlin from Frankfurt am Main was the occasion for the sale of the documents from the Frankfurt "vault"-as the Suhrkamp's basement room on Frankfurt's Lindenstraße, where

Gesine Müller, Universität zu Köln

Ә Open Access. () 2020 Gesine Müller, published by De Gruyter. (cc)BY-NC-ND This work is licensed under a Creative Commons Attribution-NonCommercial-NoDerivatives 4.0 International License. 
business documents and important correspondence with authors were stored, was called. In the winter of 2009/2010, therefore, large quantities of inventory were transported to Marbach. The number of moving boxes was listed as 2100; counting documents from the publisher's villa as well, the estate included more than twenty thousand binders and more than twenty-five thousand books from the Suhrkamp Verlag and the Insel Verlag.

The acquisition of the Siegfried Unseld estate by the DLA was the most valuable purchase the DLA archive had ever made; until then, the heart of the archive had been the collection of the Cotta Verlag, which was Goethe's and Schiller's publishing home. Since the acquisition, the Siegfried Unseld archive (Siegfried Unseld Archiv, SUA) in Marbach has gradually been made accessible for research. Speaking to the press, Ulrich Raulff, the director of the DLA, called it a stroke of luck that "only happens once in a hundred years" (Cammann). In addition to correspondence with Suhrkamp authors including Beckett, Habermas, Paz, and Cortázar, the estate also includes internal reports and editorial reports, minutes of the editorial meetings, enlightening travel reports (including some by Unseld himself), files from the advertising, licensing, and accounting departments, and much more. In spite of the limitations that one necessarily encounters when working in this archive, the material to be found here is exceptionally valuable, and that is also and especially true from a Latin American perspective. There are two reasons for this: first, because the Suhrkamp Verlag played such a decisive role in the international publishing world with respect to Latin American literature, and secondly, because the publishing house kept such unusually extensive and careful records. This means that now, for the first time in Germany, there is very comprehensive material available that can be used to examine a time period before the work of Latin American authors had been translated and published in Germany. Thus, such things as the selection processes of German publishing houses with respect to Latin American literatures can be studied very concretely, in a way that was previously not at all possible.

So much for the institutional preconditions for the material foundation of this study. But how do the publishing house's international selection mechanisms relate to Siegfried Unseld's gatekeeping strategies and possible conception of world literature? 


\section{The Selection of International Literatures at Suhrkamp}

When we look at the history of Suhrkamp's success in the field of world literature, the first phase in the establishment of its international catalogue took place from the early 1950s to the mid-1960s ${ }^{1}$. Here the work of Samuel Beckett, more than any other writer's work, stands out as of extraterritoriality that George Steiner coined in 1973 to describe a constitutive element of the Suhrkamp culture. There is a well-known passage in Beckett's Molloy that employs what critics have often drawn attention to as a "double voice", which can never be clearly traced back to one speaker and about which even the first-person narrator is not clear (Weber 110): "I had forgotten who I was (excusably) and spoken of myself as I would have of another, if I had been compelled to speak of another. Yes it sometimes happens and will sometimes happen again that I forget who I am and strut before my eyes, like a stranger" (Beckett 56) ${ }^{2}$.

For Unseld, the radicalization of extraterritoriality offered itself as a way of speaking another language, on a literary level, through an exophonic materialization: he made the particularity of the literary, as opposed to all other discourses, into the starting point for his publishing activity. On 1 June, 1962, Unseld writes to Beckett: "I would therefore like to publish an edition in three languages [...]. What do you think of this project? Of the project of an edition of your dramatic works, as well as of the 'triglot' project?"3

However, although the success stories of such writers as Samuel Beckett or Marguerite Duras at Suhrkamp cannot be denied, neither French literature nor any other international literature experienced the kind of sweeping reception that can be seen in the history of Latin American literature at Suhrkamp. The expectations of extraterritoriality move away from the intellectual imprint of the language philosophy of someone like Samuel Beckett and towards a concrete place named Macondo. What could be the reason for this?

1 With respect to the following discussion, see also Müller "Literaturen der Amerikas ...," "¿Literatura mundial ...," and "Konstruktion ..."

2 "J’avais oublié qui j'étais (il y avait de quoi) et parlé de moi comme j'aurais parlé d'un autre, s'il m'avait fallu absolument parler d'un autre. Oui, cela m'arrive et cela m'arrivera encore d'oublier qui je suis et d'évoluer devant moi à la manière d'un étranger" (Beckett, 1982: 55).

3 "J'aimerais donc publier une édition en trois langues [...]. Que pensez-vous de ce projet? Du projet d'une édition de vos œuvres dramatiques ainsi que du projet 'triglotte'?" Correspondence between Unseld and Beckett, September 1, 1969, SUA Marbach. I thank the DLA in Marbach, the heirs of Siegfried Unseld, and Michi Strausfeld for their kind permission to quote from the materials from the Siegfried Unseld archive in this article. 


\section{The Selection of Latin American Authors at Suhrkamp. Between Universalism and Exoticism}

Beginning with the first edition of Vallejo in 1963, Suhrkamp Verlag's Latin American program grew steadily and has been consistently expanded-leading to the peak in sales represented by Isabel Allende's House of the Spirits (in German, Geisterhaus) in the 1980s, with 7 million copies sold. While the 1980s and 1990s were characterized by this kind of success, the program has stagnated, relatively speaking, since the year 2000. Between 2000 and 2010, Suhrkamp only published 34 titles from Latin America. This is in sharp contrast with the numbers from 1976, when Latin America was the focus of the Frankfurt Book Fair and Suhrkamp released 17 Latin American titles in that year alone.

How can we write the history of the reception of Latin American literature in Germany-a history in which the Suhrkamp Verlag continues to play the leading role in the publishing world to this day? My thesis, as I have outlined above, is that Suhrkamp's publishing program is based on an unspoken conception of world literature that shapes the criteria for the selection of foreignlanguage literatures. The great and successful Latin American novels were absolutely exemplary cases of these European-defined criteria of world literature. By looking at Octavio Paz, it will be possible to demonstrate how Unseld, as the gatekeeper, made this concept of world literature into a central foundation of his publishing work with Latin American writers.

First of all, let us briefly review the history of Latin American literary production. The so-called 1960s boom in Latin American literature, during which the novels of such writers as García Márquez, Vargas Llosa, Fuentes, and Cortázar quickly became best-selling sensations, was the result of a number of different circumstances. The Cuban revolution can be seen as the beginning of this process, although the word boom certainly refers to the purely economic successes of this literature, which was mostly due to the work of the Barcelona publishing house Seix Barral. But how are the texts of the boom related in terms of content? Julio Cortázar probably best expresses what it is that they have in common: "What is the boom if not the Latin American people's most extraordinary achievement of consciousness of its own identity?” (cited in Avelar 28) ${ }^{4}$. It does not matter whether this consciousness was achieved through the use of pre-Columbian myths, cyclical structures of time, or experimental narrative methods.

4 “¿[...] qué es el boom sino la más extraordinaria toma de conciencia por parte del pueblo latinoamericano de una parte de su propia identidad?” (cited in Rama 244). 
How, then, was this literature received in Germany? If we cast even a cursory look at the reviews that followed the publication of, for example, Gabriel García Márquez's One Hundred Years of Solitude (which appeared in Germany as Hundert Jahre Einsamkeit in 1967) or Mario Vargas Llosa's The Green House (Das grüne Haus, 1965), it quickly becomes clear that the unspoken yardstick is the concept of world literature. Vittoria Borsò has keenly detailed the connections between world literature as a selection criterion and the publishers' reception of these works. That which she was able to establish for García Márquez's Hundert Jahre Einsamkeit, which was published by Kiepenheuer \& Witsch, also applies to Suhrkamp's authors, including Vargas Llosa, namely that what the literary critics stressed as indicators for membership in the canon of world literature were both the assimilation of European and international traditions and, at the same time, the integration of oral narrative strands from pre-Columbian cultures. The writers of the boom were described as having enriched the European and Western traditions with the lavish colors of the tropical world (Borsò 236).

Another feature of these novels that raised them to the level of world literature, following Borsò's argument, is the fact that in (for instance) the mythical Amazonian spot on the Marañón River, which is comparable to García Márquez's Macondo, not only the history of Latin America, but in fact the history of the world takes place. This is suggested by the rich and plentiful allusions to the Book of Genesis and to archetypal myths of origin. In summary, then, we can say that the reception of these Latin American writers by literary critics and literary theorists mostly stressed their ability to connect to modern world literature, while highlighting the combination of representations of alterity that were as exotic as possible with the postmodern narrative processes that had been established in Europe. The paradigm of identity, and concretely the search for a specifically Latin American identity, was the decisive criterion for justifying the novels as belonging to world literature (cf. Borsò 236).

How do the positions expressed by the publishing industry compare to this? We can find strong and vivid material with which to address this question in the archival holdings of Suhrkamp Verlag, mostly in Unseld's correspondence with the various authors, but also in his exchanges with his closest Latin America consultants, Michi Strausfeld and Wolfgang Eitel. We also find evidence of Unseld's encounters with leading Latin Americanists such as Klaus Meyer Minnemann, Dieter Janik, and Karsten Garscha. In May 1979, Unseld wrote in his journal: "Octavio Paz made a strong impression on me. A disposition in whom poetry and erudition, wisdom and knowledge are united. I invited Paz, as 


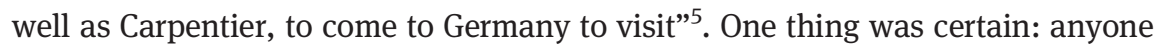
who was part of the illustrious circle of non-German Suhrkamp authors had to be considered as potentially a part of world literature. It seems unquestionable that Suhrkamp's publishing program was to be equated with world literature. The fact that Octavio Paz, in particular, fulfilled this function exceptionally well may also have to do with his affirmatory understanding of a genuinely European modernity.

\section{The Publisher Siegfried Unseld as Octavio Paz's Gatekeeper}

The condolence letter that Unseld wrote to Octavio Paz's widow, María-José, on 30 April, 1998 (ten days after Paz's death on April 20th of that year), is a telling document in our examination of Unseld's gatekeeper function towards Paz ${ }^{6}$. The following lines provide a striking description of the two broad dimensions of the relationship between Paz and Unseld: "For all of us Octavio is the great author. We are proud to have taken care of his work. And you can be sure that we will continue to work for him and his work, to have his books in print and to publish new ones, so that his ideas can continue to irradiate and illuminate the German public"7. We hear two voices of Unseld here. First is the voice of the resourceful, successful businessman, with foresight and mercantile flair, who years earlier, in a strategic move for his publishing agenda, had taken Paz on as part of his Latin American program and who was then retroactively "paid back" for his investment and confirmed in his trust in the Mexican author when Paz was awarded, most notably, the Cervantes Prize in 1981 and the Nobel Prize in 1990. But we also hear another voice here, which speaks of Unseld's image of (or perhaps more strongly put, his projection onto) Paz the literary writer as the 20th-century Latin American Enlightenment thinker whose ideas-marked by their progressive nature, their vision, their educational nature, and, not least, their standing as part of world literature-must not be allowed to dry up. By way of illustration of the public image of Paz in the 1980s, let me cite the former German Federal President Richard von Weizsäcker, who in 1984 gave

\footnotetext{
5 "Octavio Paz hinterließ mir einen großen Eindruck. Eine Persönlichkeit, in der sich Poesie und Gelehrsamkeit, Weisheit und Wissenschaft vereinen. Ich habe Paz und auch Carpentier zu einem Besuch nach Deutschland eingeladen.” Unseld's travel report, Paris, 20-22 May, 1979, SUA Marbach.

6 I rely in this chapter on Müller and Bubel.

7 SUA Marbach.
} 
the speech celebrating the winner of the peace prize awarded by the German book industry: "Octavio Paz is on his way to becoming the defining voice of Latin American culture, in fact its conscience” (Suhrkamp Verlag 22).

Unseld's programmatic understanding of what constituted a "publicationworthy" and potentially successful Suhrkamp author on the Latin America list can only be grasped against the background of the classically established and primarily German-language poetics of authorship within the Suhrkamp universe, as well as in the context of the West German cultural bourgeoisie (professionals who prized education and culture) of the 1970s and 1980s, as we can see from a closer examination of Octavio Paz's poetic, existential, religious, and sociopolitical ideas and beliefs, which made him interesting and relevant to Unseld and to Suhrkamp's Latin America program. These are operational, poetological parameters that were essentially able to function as a master key allowing entry into the Latin America list in the German-language market according to the guidelines set out by Unseld and Suhrkamp. When we look closely at the supposedly exemplary nature of Paz's work, what becomes clear is not only the degree to which Unseld promoted the reception of the Mexican writer in Germany through the influential gatekeeping of his publishing decisions, but also the way in which Unseld's concrete interests shaped his work, particularly his attempts to group Paz among the kaleidoscope of European poets and thinkers that Unseld represented in his publishing program.

In his report on the meeting he had with Paz in Paris in May 1979 (probably their first meeting), Unseld describes how impressed he was at the Mexican author's demeanor and depth of knowledge. He writes: “An impressive presence, poet and scientist, wise man and man of knowledge. One has the impression that the experiences of long periods of social and literary revolutions have

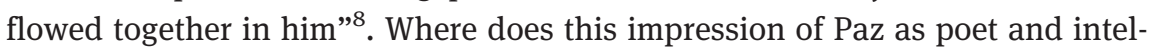
lectual come from? The obvious question arises as to whether and to what extent Paz's work in fact merits this (projected) point of view, or whether Unseld is not, for pragmatic reasons related to the politics of publishing, simply superimposing Suhrkamp's categories onto Paz's person and oeuvre. What are the substantive and formal aspects and means with which the "wise and knowledgeable" Paz was able to cement his status as a Latin American polymath and Enlightenment figure in Unseld's perception? To understand this connection better, we need to outline a short and partial description of Unseld's understanding

8 "Eine imponierende Erscheinung, Poet und Wissenschaftler, Weiser und Wissender. Man hat den Eindruck, in ihm seien Erfahrungen langer Zeiten von sozialen und literarischen Revolutionen zusammengeflossen.” Unseld's travel report, Paris, 20-22 May, 1979, SUA Marbach. 
of a world-class "Enlightenment figure" or "man of knowledge". This can be demonstrated in particular through the comparative categories that Unseld used in order to try to make Paz comprehensible within Unseld's own understanding of art. Thus, Unseld sees the triad of Cortázar, Paz, and Carpentier as the "greats of Latin American literature. All three of them impressive, because in themselves they reflect not only that which is their own, and their own continent, but also the others"'. Thus, Unseld classifies Paz as a universalist author, as it were, one who can transcend his own national and ethnic limitations and constraints to grapple with the-supposedly-higher existential questions in his work, a "world traveler"10 who oscillates between the reference points of Latin America and Europe in his thinking. Behind this intellectual elevation of Paz to the status of grand old man of Latin American literature-along with Cortázar and Carpentier, the "Thomas Mann of Latin America"11_however, we might also guess that there is a trick involving editorial politics: these writers represented Cuba, Mexico, and Argentina, and thus Unseld was able to give a face to the most politically interesting regions of Latin America and make them concrete for the postwar German bourgeoisie.

In addition to these considerations of editorial politics, Unseld's reception of Paz's poetics was, on the one hand, particularly colored by the "Enlightenment" model mentioned above; on the other hand, Unseld was also deeply impressed by a lecture that Paz gave in Frankfurt in the summer of 1980. From the Mexican writer's various aesthetic and poetological comments in that lecture, Unseld extracts what he considered to be the central message: "Yes, it is true: 'América Latina es una cultura'-'Latin America is one culture"”12. In spite of its very great diversity in terms of politics, culture, ethnicity, language, and, ultimately, literature, Unseld would like for Latin America to be understood as a homogeneous whole whose political individuation process is not only reflected in the contemporary literature that accompanies it, but is in fact actively guided and propelled by that literature. Thus, Suhrkamp often advertises its Latin American literature using the word "existentialist" and characterizes Latin America as a kind of "unspoiled" emotional (continental) space that is under construction. It should

9 "Großen der lateinamerikanischen Literatur. Alle drei beeindruckend, weil sie nicht nur das Eigene, den eigenen Kontinent, sondern auch die anderen in sich reflektieren.” Unseld's travel report, Paris, 20-22 May, 1979, SUA Marbach.

10 As Michi Strausfeld puts it in a draft of a Suhrkamp report, probably dating from 1980 (esNF-Lateinamerika, 1980 (?), SUA Marbach).

11 Unseld's travel report, Paris, 20-22 May, 1979, SUA Marbach.

12 “Ja, es ist wahr: 'América Latina es una cultura'-'Lateinamerika ist eine Kultur.”' Siegfried Unseld, Letter to O. Paz, 4 July, 1980, SUA Marbach. 
therefore not be surprising that in 1979, Suhrkamp Verlag's Latin America list was promoted under the title 17 Authors Are Writing the Novel of the Latin American Continent (17 Autoren schreiben am Roman des lateinamerikanischen Kontinents), and that in that document, Unseld notes pithily that:

Of all the contemporary non-German literatures, it is Latin American literature that seems to me to be the most important one for the coming decade. It is a particular kind of existentialist literature that in other countries can now, for whatever reasons, only be written in individual cases. This literature encourages a new kind of education in feelings, and its characters, who are so very real, are not afraid of naming the values of life and assigning to them their relative positions ${ }^{13}$.

This kind of "existential" Latin American literature, one that is able to "name the values of life" and even to kindle a new sort of sentimental education, nevertheless, in Unseld's understanding, continues to operate according to known coordinates. Writing about Octavio Paz's poem "Piedra de Sol” ("Sunstone”), which had what he called a "hunger for being"14 (Hunger nach Sein) that deeply impressed him, Unseld noted that it was the way the poem ended that particularly fascinated him, the "symbol of the river 'that goes curving, / advances and retreats, goes roundabout, / arriving forever,' the soft water in motion"15. It would not seem to be a coincidence that Unseld valued the metaphors, images, and tropes in Paz's work that are topically charged in literary and philosophical history, including such tropes as Heraclitus's panta rhei, invoked here. Given the orientation of the Latin America program and the publishing house's strategy of a "Latin American awakening", such universally interpretable and historically freighted metaphors would in fact be required in order to help the

13 "Von allen außerdeutschen zeitgenössischen Literaturen scheint mir die lateinamerikanische sicherlich für das nächste Jahrzehnt die wichtigste zu sein. Es ist eine besondere Art existentieller Literatur, wie sie in anderen Ländern, aus welchen Gründen auch immer, nur noch in einzelnen Fällen geschrieben werden kann. Diese Literatur macht Mut zu einer neuen Erziehung zu Gefühlen und ihre so realen Gestalten scheuen sich nicht, Werte des Lebens zu benennen und in ihrem Rang zu bestimmen.” Suhrkamp catalogue for the 1979 Frankfurt Book Fair, SUA Marbach.

14 Unseld's travel report, Paris, 20 May, 1979, SUA Marbach.

15 "Piedra de Sol" is one of Octavio Paz's major works, which Unseld is known to have read. It was published in German by Suhrkamp in 1977 in the volume Octavio Paz. Gedichte (Octavio Paz. Poems) and again in 1979 in the volume Suche nach einer Mitte. Die großen Gedichte (Search for a Center. The Great Poems). Unseld's original comment is "Symbol des Flusses, als der, 'der sich windet, verdrängt, zurückweicht, einen Umweg wandelt und immer ankommt', das weiche Wasser in Bewegung”. Unseld's travel report, Paris, 20 May, 1979, SUA Marbach. Paz's lines are "[un caminar de río] que se curva, / avanza, retrocede, da un rodeo / y llega siempre” (Paz, Piedra 1). 
German-speaking public, which had almost no knowledge of Latin America, to gain a more concrete understanding of the region. In addition, such rhetorical devices qualified Paz, a Mexican author who therefore still seemed "exotic" at that time in the German-speaking world, to be incorporated into the group of historically significant Suhrkamp authors. We should not forget that it was not Unseld's ambition to publish "the excavations of odd esoteric documents" in his now-celebrated Library of Modern Classics (Bibliothek der Klassiker der Moderne), "but rather [to strive for] a unity of purpose in spite of the most divergent themes, in order to justify the claim that here, literature becomes an escape into life" (Unseld 9) ${ }^{16}$.

This “escape into life” appears to be, in Unseld's conception, something specifically modernist, shaped by Nietzsche’s emphatic “yes to life” (Ja zum Leben) and Bergson's “vital force” (élan vital), as well as by the politically committed literature of the Weimar Republic (including Hesse and Brecht) and by modernity's existentialist manifestations (including Sartre and Camus). The more points of connection and overlap that could be found between these literary greats and the aesthetics of the Latin Americans, the more valuable their work seemed to Unseld. The fact that, for Unseld, literature could not be separated from social engagement and sociopolitical action is demonstrated not only by the programmatic direction taken by the Suhrkamp Library after the Second World War, but also by Unseld's highly positive assessment of socially engaged literary figures who did not simply loiter in the ivory tower of art for art's sake. Paz's aesthetic is distinct from such artistic escapism (the kind that we see in symbolism), without however allowing itself to be made into a literary mouthpiece for political and social positions. It is namely all too often impossible to separate politically engaged literature from the teleological thought patterns of bourgeois rationalism, and the task of the poet is to create a protected space through poetry in which ideas and knowledge that transcend their times and are unaffected by the zeitgeist can survive, freed of any appropriation by bourgeois categories of thought. Thus, in Sor Juana or, The Traps of Faith, Paz writes:

Bourgeois rationalism is, in a manner of speaking, constitutionally averse to poetry. Hence poetry, from the beginnings of the modern era-that is, since the last years of the eighteenth century-has been a form of rebellion. Poetry is not a genre in harmony with the modern world; its innermost nature is hostile or indifferent to the dogmas of modern times, progress and the cult of the future. [...] Poetry, whatever the manifest content of the poem, is always

16 "keine Ausgrabungen abseitiger Gelegenheitsarbeiten [zu publizieren], vielmehr trotz divergierendster Themen eine Geschlossenheit im Ziel [anzustreben], die die Behauptung rechtfertigt: Hier wird Literatur zur Flucht in das Leben.” 
a violation of the rationalism and morality of bourgeois society. Our society believes in history: newspapers, radio, television, the now; poetry, by its very nature, is atemporal. $(5)^{17}$

Paz here refuses to allow bourgeois categories of value to politicize, appropriate, or impose their influence on literary production, assigning a unique rebellious power to poetry and the poet, a power that has the ability to produce a genuinely other epistemology: a timeless practical knowledge that generates a morality beyond positivism, rationalism, or empiricism. It is through this characteristic kind of literary politicization that the poet fulfills his responsibility to society, as Paz stresses in his "La letra y el cetro" ("The Letter and the Scepter"): "But we cannot renounce politics: that would be worse than spitting at the sky-it would be spitting at our own selves" $(754-755)^{18}$. What Unseld so values in Paz's work is also that very creative, rebellious force that the Mexican writer sees in the medium of literature and poetry. This establishment of poetry as a separate, independent, epistemological category can be found in many of the modernist poets connected with Suhrkamp Verlag, for instance in the work of Hugo von Hofmannsthal, whom Unseld greatly esteemed and whose 1907 essay "The Poet and Our Time" ("Der Dichter und diese Zeit") displays striking similarities with Paz's thinking:

He [the poet] may not shrink from any thought that presses itself on him as if he were from a different order of things. For each thing must fit into his order of things. In him everything has to and wants to come together. He is the one who joins the elements of the age in himself. In him or nowhere is the present [...]. As the most inward sense of all human beings creates time and space and the world of things around them, so does he create out of past and present, from animal and human being and dream and thing, from large and small, from sublime and worthless, the world of relationships ${ }^{19}$. (Hofmannsthal 42)

17 "El racionalismo burgués es, por decirlo así, constitucionalmente adverso a la poesía. De ahí que la poesía, desde los orígenes de la era moderna-o sea: desde las postrimerías del siglo XVIII-se haya manifestado como rebelión. La poesía no es género moderno; su naturaleza profunda es hostil o indiferente a los dogmas de la modernidad: el progreso y la sobrevaloración del futuro [...]. La poesía, cualquiera que sea el contenido manifiesto del poema, es siempre una transgresión de la racionalidad y la moralidad de la sociedad burguesa. Nuestra sociedad cree en la historia-periódico, radio, televisión: el ahora-y la poesía es, por naturaleza, extemporánea” (Paz, Sor Juana 16).

18 "Pero no podemos renegar de la política; sería peor que escupir contra el cielo: escupir contra nosotros mismos."

19 "Keinen Gedanken der sich an ihn [den Dichter] drängt, darf er von sich scheuchen, als sei er aus einer anderen Ordnung der Dinge. Denn in seine Ordnung der Dinge muß jedes Ding hineinpassen. In ihm muß und will alles zusammenkommen. Er ist es, der in sich die Elemente der Zeit verknüpft. In ihm oder nirgends ist Gegenwart [...]. Wie der innerste Sinn aller Menschen Zeit 
For Unseld, Hofmannsthal certainly represented one of the most important points of comparison for evaluating Paz's work. Thus, a letter from Unseld to Paz, dated 4 July, 1980, in which Unseld reviews Paz's weeklong visit to Germany with his wife, María-José, is a testament to Unseld's drive, as Paz's gatekeeper, to position Paz within the tradition of Suhrkamp's established writers and German-language intellectual giants. During Paz' journey through West Germany (visiting Bonn, Frankfurt, and Heidelberg), not only was a visit to the Goethe-Haus "a matter of course", but they were also shown the "Hofmannsthal treasures" in the Goethe library, because, according to Unseld, "Hofmannsthal was, after all, one of the few German poets who had mastered Spanish" ${ }^{20}$. Against the backdrop of this comparison to Hofmannsthal, the following passage from Unseld's 1979 travel journal, already cited above, becomes even more significant:

In these times, when the belief in progress and the historical process seems to be waning, he $[\mathrm{O} . \mathrm{Paz}]$ is an important person for me. His experience, from a half-century of upheavals is this: no one knows what the future looks like, we must be vigilant and watchful, we must be skeptical, but we should also hope. And for him, the most important thing is that the highest value is not the future, but rather the present. "The future is not the time of love: what a person truly wants, he wants now. He who is building the house of future bliss is erecting the prison of the present time". And his verdict on progress is this: "It has peopled history with the wonders and monstrosities of technology, but it has depopulated the lives of human beings: it has given us more things, but not more being" ${ }^{21}$.

Here, Unseld is once again critiquing the bourgeois belief in progress and the dichotomous relationship between what Erich Fromm calls the "being and having" of bourgeois categories of value. In the 1996 interview Octavio Paz: El poeta en su tierra (Octavio Paz: The Poet in His Land), Paz expresses that ambivalence like

und Raum und die Welt der Dinge um sie her schafft, so schafft er aus Vergangenheit und Gegenwart, aus Tier und Mensch und Traum und Ding, aus Groß und Klein, aus Erhabenem und Nichtigem, die Welt der Bezüge” (Hofmannsthal, “Der Dichter” 244-245).

20 "Hofmannsthal war ja einer der wenigen deutschen Dichter, die des Spanischen mächtig waren.” Siegfried Unseld, letter to O. Paz, 4 July, 1980, SUA Marbach.

21 "Für mich ist er [O. Paz] in unserer Zeit, wo der Fortschrittsglaube und Glaube an den historischen Prozess zu verdämmern scheint, eine wichtige Persönlichkeit. Seine Erfahrung aus einem halben Jahrhundert der Umstürze: niemand weiß, wie die Zukunft aussieht, wir müssen wachsam sein und aufpassen, skeptisch sein, aber wir sollten doch auch hoffen. Und für ihn ist das Wichtigste: der höchste Wert ist nicht die Zukunft, sondern die Gegenwart. 'Die Zukunft ist nicht die Zeit der Liebe: was der Mensch in Wahrheit will, das will er jetzt. Derjenige, der das Haus der künftigen Glückseligkeit konstruiert, errichtet das Gefängnis der Gegenwart.' Und das Urteil über den Fortschritt lautet: 'Er hat die Geschichte mit den Wundern und Monstren der Technik bevölkert, aber er hat das Leben der Menschen entvölkert, er hat uns mehr Dinge gegeben, nicht mehr Sein."” Unseld's travel report, Paris, 20-22 May, 1979, SUA Marbach. 
this: "there is a radical opposition between the values of modern society and poetry. The culture of capitalist society is fundamentally grounded in the moral value of utility. And poetry is always an expense, a waste. There is an incompatibility between bourgeois morality-which is the morality of thrift and frugality-and poetic morality, which is the morality of giving, of wastefulness" 22 . This fundamental discrepancy in human nature results, says Paz, in a disregard of the present. Here we can recognize echoes of the radical Sartrean existentialism of the 1950s and thus, too, of a further European intellectual tradition that even more strongly underscores Unseld's endeavor to incorporate Paz into his kaleidoscope of influential (European) thinkers and writers.

\section{Conclusion}

While it is the classic writers of German modernism, such as Hugo von Hofmannsthal or Thomas Mann, who are referenced as yardsticks, in another context Siegfried Unseld, Paz's gatekeeper, draws comparisons to contemporary leftleaning cultural theorists such as Herbert Marcuse. In his May 1979 travel journal, Unseld writes: "Then Octavio Paz comes into the hotel with his wife and we drive to the Grand Vefour to eat [...]. He modifies what Marcuse had said not long before about the zest for life"23. The Suhrkamp Verlag as the "theory forge" of the non-dogmatic left of the 1960s to the 1980s, the sociopolitical activism of the publishing house in general and of Unseld in particular, and the role that the reception of Octavio Paz took on for Unseld in this context have a direct connection with the level of political interest in Latin America: in the 1960s and 1970s, Latin America becomes a kind of sociopolitical laboratory or great new hope for the Western European and especially the German left, and later, with its military dictatorships, served as a legitimation of the critique of capitalism using dependence theory. The literary interest in Latin America, then, should be seen as the flip side of this political interest and of the political engagement for a more socially just world, in addition to providing a fictional underpinning for the theoretical critique

22 "hay una oposición radical entre los valores de la sociedad moderna y la poesía. La cultura de la sociedad capitalista está basada fundamentalmente en la moral de la utilidad. Y la poesía siempre es un gasto, un desperdicio. Hay incompatibilidad entre la moral burguesa-que es la moral del ahorro-y la moral poética, que es la moral del dar, del despilfarro" (Paz and Peralta). 23 "Dann kommt Octavio Paz mit seiner Frau ins Hotel, wir fahren zum Essen ins Grand Vefour [...]. Dann variierte er für sich das, was ein paar Tage vorher Marcuse in den Römerberggesprächen zum Thema 'Lebenslust' ausgeführt hatte.” Unseld's travel report, Paris, 20-22 May, 1979, SUA Marbach. 
of capitalism. What is considered a question of identity from the Latin American point of view is understood as a demand for social justice and cultural acknowledgment from the European or, more specifically, the German perspective.

Unseld's quest for legitimation is noteworthy. He wants Latin American literature to be taken seriously enough that it will be able to find justified admission into the world literary canon: "I must add that Latin American literature is a newcomer. It is the youngest of all Western literatures. [.. .] Latin America is a Far West" ${ }^{24}$. The criterion of operating as a Far West is a way of shifting the established category of an affirmative Orientalism-likewise an indicator of world literature-to a transatlantic sphere and thus taking on existing measures of value for the literary staging of the Other as the exotic. The double criterion of the ability to be integrated into the German cultural tradition (in the form of highly canonical authors) and a left-leaning theoretical formation created a reception filter that served the company well, pragmatically connecting some of the central themes of the "Suhrkamp culture": religion, ethics, and existentialism.

\section{Works cited}

Avelar, Idelber. The Untimely Present: Postdictatorial Latin American Fiction and the Task of Mourning. Duke University Press, 1999.

Beckett, Samuel. Molloy: A Novel. Trans. Patrick Bowles in collaboration with the author. Grove Press, 1955.

---. Molloy. Éditions de Minuit, 1982.

Borsò, Vittoria. "Europäische Literaturen versus Weltliteratur-Zur Zukunft von Nationalliteratur." Jahrbuch der Heinrich-Heine-Universität Düsseldorf. Ed. Alfons Labisch. Heinrich-Heine-Universität Düsseldorf, 2004, pp. 233-250. http://www.uniduesseldorf.de/Jahrbuch/2003/PDF/Borso.pdf, last visit 18/09/18.

Bürger, Jan. “Aber unsere große Entdeckung. . . war Siegfried Unseld.” Jahrbuch der Deutschen Schillergesellschaft, 54, 2010, pp. 13-20.

Cammann, Alexander. “Im Papier-Gebirge.” Die Zeit, 11 Feb. 2010, p. 7.

Hofmannsthal, Hugo von. "The Poet and Our Time." Hugo von Hofmannsthal and the Austrian Idea: Selected Essays and Addresses, 1906-1927. Ed. and trans. David S. Luft. Purdue University Press, 2011, pp. 33-51.

--.. "Der Dichter und diese Zeit." Gesammelte Werke in zehn Einzelbänden. Vol. 8: Reden und Aufsätze I (1891-1913). Ed. Bernd Schoeller. S. Fischer, 1979 [1907], pp. 229-258.

Marling, William. Gatekeepers. The Emergence of World Literature and the 1960 s. Oxford University Press, 2016.

24 "Ich muß hinzufügen, daß die lateinamerikanische Literatur ein Neuankömmling ist. Sie ist die jüngste aller westlichen Literaturen. [.. . ] Lateinamerika ist ein Ferner Westen.” Unseld's travel report, Paris, 20-22 May, 1979, SUA Marbach. 
Müller, Gesine. “¿Literatura mundial o literaturas mundiales? Un estudio de caso de las letras latinoamericanas en la editorial Suhrkamp." América Latina y la Literatura Mundial: mercado editorial, redes globales y la invención de un continente. Eds. Gesine Müller and Dunia Gras. Iberoamericana/Vervuert, 2015, pp. 81-98.

---. "Konstruktion von Weltliteratur und Verlagspolitiken. Der Lateinamerika-Nachlass des Suhrkampverlags." Buchmarkt, Buchindustrie und Buchmessen in Deutschland, Spanien und Lateinamerika. Ed. Marco Thomas Bosshard. LIT, 2015, pp. 147-160.

--.. "Literaturen der Amerikas und ihre Rezeption in Deutschland." Verlag Macht Weltliteratur. Lateinamerikanisch-deutsche Kulturtransfers zwischen internationalem Literaturbetrieb und Übersetzungspolitik. Ed. Gesine Müller. tranvía, 2014, pp. 117-132.

Müller, Gesine, and Sylvester Bubel. "Entre estética y política. Ideas de una literatura mundial en la correspondencia Unseld-Paz." iMex. México Interdisciplinario. Interdisciplinary Mexico, vol. 5, no. 10, 2016, pp. 108-117.

Paz, Octavio. "La letra y el cetro." Obras completas. Vol. 5: El peregrino en su patria: Historia y política de México. Galaxia Gutenberg/Círculo de Lectores, 2002, pp. 751-755.

--.. "The Sunstone." The Collected Poems of Octavio Paz, 1957-1987. Trans. Eliot Weinberger, New Directions Books, 1991, p. 1.

---. Sor Juana or, The Traps of Faith. Trans. Margaret Sayers Peden. Harvard University Press, 1988.

---. Sor Juana Inés de la Cruz o Las trampas de la fe. Fondo de Cultura Económica, 1985.

---. "Alrededores de la literatura hispanoamericana" [Lecture given at Yale University in 1976]. In/Mediaciones. Seix Barral, 1979, pp. 25-37. Also appeared in: Vuelta, vol. 1, no. 5, 1977.

---. Piedra de sol. Tezontle, 1957.

Paz, Octavio, and Braulio Peralta. "Esa parte irracional del hombre, la poesía." El poeta en su tierra: Diálogos con Octavio Paz. Ed. Pámpano Servicios Editoriales S.A. de C.V./H. Cámara de Diputados, LXII Legislatura, 2014, pp. 39-47. http://biblioteca.diputados. gob.mx/janium/bv/md/LXII/poet_tierr.pdf, last visit 14/12/18.

Rama, Ángel. La novela latinoamericana 1920-1980. Procultura, 1982.

Siegfried Unseld archive (SUA) at the German Literary Archive (Deutsches Literaturarchiv) in Marbach.

Suhrkamp Verlag. Suhrkamp Verlagsgeschichte 1950-1990. 40 Jahre Suhrkampverlag. Suhrkamp, 1990.

Unseld, Siegfried. "Kleine Geschichte der Bibliothek Suhrkamp." Klassiker der Moderne-Ein Lesebuch. Ed. Hans-Ulrich Müller Schwefe. Suhrkamp, 1989, pp. 7-23.

Weber, Julia. Das multiple Subjekt. Randgänge ästhetischer Subjektivität bei Fernando Pessoa, Samuel Beckett und Friederike Mayröcker. Fink, 2010. 
